\title{
Financial Intermediation, Capital Composition and Income Stagnation: The Case of Europe
} Andreas Samatas $^{\mathrm{a}}$, Michalis Makrominas $^{\mathrm{b}}$, Andrea Moro $^{\mathrm{c}}$

\begin{abstract}
a TeleTrade-DJ International Consulting, 88 Arch. Makarios Avenue, 1077, Nicosia, Cyprus b Frederick University Cyprus, Department of Maritime Studies, 7, Y. Frederickou Str. Pallouriotisa c Cranfield University, School of Management, Cranfield, Bedford MK43 0AL, United Kingdom
\end{abstract}

\begin{abstract}
We look into the role of financial intermediation in inducing the European financial crisis of 2008 by exploring the effects of overall lending, and the allocation of credit to specific categories of borrowers, namely households vs. firms. We find that for the EU26 during the period 1995-2008, excessive household leverage through mortgage lending exerted a "crowdingout" effect on availability of credit to support innovation and productive investment. The crowding out effect ultimately translated into a GDP growth that was decoupled from real household income. In this article we explain that shifting credit towards mortgages and away from corporate projects is consistent with rational behaviour based on historical trends aimed at minimizing short-term risk for each individual bank. Nevertheless, as a whole, the sum of individual risk-reducing attitudes generated a long-term systemic risk.
\end{abstract}

JEL: O16, E22, O40

Keywords: financial-intermediation, fixed-capital-formation, economic-growth 


\section{Introduction}

Kindleberger's seminal work on mania panics and crashes stresses the fact that the world's economy is subject to more or less regular cycles of inescapable booms and busts (Aliber and Kindleberger, 2015). The economy slowdown that hit Europe and the world in $2007 / 2008$ is the very last of the

crises the world has faced. Even if we assume that in a financial crisis there are some inevitable components, it is anyway beneficial to investigate its causes. Our research focuses on the role of banks' behaviour - in particular their decision of expanding lending in general, as well as expanding lending to households as opposed to firms - as factors that stimulated unbalanced economic development (biased towards consumption and non-productive assets such as properties) and ultimately induced/amplified the European financial crisis of 2008. In order to investigate the topic, we rely on two major approaches that describe the role of the financial system on economic growth, namely the "finance-led" and the "structural root" approaches.

The "finance-led" approach explores the role of financial institutions as channels that stimulate the economy by providing credit. Empirical evidence based on this approach shows that financial intermediation has been detached from the real sector (Haiss et al., 2016), that bank credit had a negative effect on short-run growth (Narayan and Narayan, 2013) and that cross border financial flows have been an underlining factor of the financial crisis (Baldwin and Giavazzi, 2015). Previous research also explored the finance-induced crises caused by general excessive lending (Büyükkarabacak and Valev, 2010; Reinhart and Rogoff, 2009) and by financial innovation gone bad, that is new financial products, such as collateralized debt securities, that adversely affected the economy (Brunnermeier, 2009). Closer to our area is the research that examined bank practices of lending to households, primarily in the form of 
mortgage lending, without considering income standards (Jordà et al., 2016; Mian and Sufi, 2014). The major criticism of the "finance-led" approach in explaining the financial crisis is that it only focuses on the amount of finance, thus failing to account for ex-ante financial distortions in the economy, where by distortion we mean the mis-allocation of finance among the different economic actors (firms vs. households). The second approach we rely on, the "structural-roots", argues that the excessive financial lending to households was the ex-post policy implemented as a response to the pre-existing low levels of household income and productive investment (Barba and Pivetti, 2009; Fitoussi and Saraceno, 2010; Stiglitz et al., 2009; Wisman, 2013). By increasing lending to households in order to stimulate the economic growth, the financial system kept artificially high both the demand of products and the demand of non-productive assets (namely properties). Evidence of the structural-roots approach can be found in the fact that high leverage and low interest rates (forces that typically stimulate inflation) did not create inflation, suggesting an economy in need of higher leverage in order to achieve greater GDP growth (Summers, 2014).

In line with the finance-growth literature which investigates the links of finance to sources of growth such as capital formation, investment and productivity (Arcand et al., 2015; Beck et al., 2000; Benhabib and Spiegel, 2000; Rousseau and Wachtel, 2011) we test an empirical model that expands the above mentioned finance-led and the structural-roots approaches to shed light on the causal mechanism between finance and growth/crisis. We use disaggregated data of financial development, capital formation and income for the $26 \mathrm{EU}$ members between 1995 and 2008 and rely on GMM dynamic panel estimation techniques (where lag variables are used as valid instruments in accordance to the Arellano and Bond (1991) 
approach), as well as a Fixed Effects-2SLS simultaneous regressions, to establish results. Both methods used aim at alleviating the finance/growth predicament of endogeneity.

We find that excessive household leverage, based on mortgages, supported households' investment in non-productive assets (i.e. residential properties), and exerted "crowding-out" effects on finance to firms (i.e. investment on assets that can be allocated to production and innovation). In other words, we find that in the pre-crisis period, banks mis-allocated funds by expanding lending to households at the expense of firms. Such a behavior stimulated an economic growth where GDP growth was decoupled from real household income: while the GDP was marginally increasing, household real income was decreasing and their debt was increasing. Furthermore, we find that the effects of household leverage are valid for both the financially developed and developing EU members even if the former suffered the greatest negative effects of excessive household leverage. As firms in financially developed countries were accustomed to rely more heavily on banks for project financing, the credit constraints imposed by shifting lending towards households bore the greatest consequences. In contrast, for financially developing countries, firms' growth supported by debt was reduced. Thus, in the latter case, shifting lending from capital formation (firms) to unproductive assets (household) had a marginal negative impact on firm's capability to invest in productive assets so that the growth enjoyed by the country (in terms of GDP) benefitted only very marginally the households.

Our results tend to reject the pure "financial-led" argument that the cause of financial crisis is a general excessive lending sic et simpliciter. However, our results tend also to reject the "structural roots" argument in its basic stand-alone form. Intriguingly, we find evidence that both the "financial-led" and the "structural-roots" arguments have their merits: both excessive lending 
and misallocation of the credit is found to be the ex-ante reason of the financial crisis. Our analysis suggests that while finance in the form of lending to households may initially boost aggregate demand and consumption, when it is not allocated to support capital formation, it does not find its way back into the household through the production cycle. The financial development does not necessarily create the conditions in terms of investment for the creation of the required income to repay for the accumulated debt (Turner, 2015). What affects a balanced economic development is the way in which finance is allocated and used together with the amount of finance injected in the system that affects a balanced economic development.

The paper contributes to the literature by helping to clarify the role of financial intermediation in inducing the European financial crisis of 2008. By investigating the links behind finance, capital formation and growth we illustrate the mechanisms behind the decoupling of GDP growth from household income growth (Barba and Pivetti, 2009; Wisman, 2013), show how financial intermediation can be detached from the real sector (Haiss et al., 2016); and explain the ways in which bank credit may exert a negative effect on long-run growth (Narayan and Narayan, 2013). The evidence derived from this study stresses how bank-specific financing choices that are perfectly rational in the short term can structurally distort an economy and lead to unsustainable growth by not letting credit take its economic function of stimulus to productive investments. We show that excessive finance is not a mere byproduct of an era characterized by reduced productive investment and the divergence paths of household income to GDP, or that finance, as such, causes instability in a structurally sound system. Instead, we show that excessive and rapid credit allocation towards households and mortgages and the related constrained access to credit for firms can have structural implications on the economy. 
The remaining part of the paper is structured as follows: Section 2 illustrates previous research, section 3 details the variable construction while section 4 presents descriptive statistics and discusses the estimation methods. Section 5 shows the results, section 6 provides the relevant discussion and section 7 concludes.

\section{Literature Review}

In the last ten years a good amount of research looked at the causes of the economic and financial crisis. Research finds that total factor productivity (TFP) has an impact on country growth (OECD, 2009) and their capability to catch up (Banerjee and Jesenko, 2015; Kim and Park, 2018). It stresses that financial development is a key factor in pushing TFP (Arizala et al., 2013; Han and Shen, 2015) and that financial misallocation is a factor that affects the TFP (Dias et al., 2015). In addition, research investigates the impact of the financial crisis on TFP (Chouard et al., 2014; Ollivaud and Turner, 2015; Sandliers and Wright, 2014). All in all, a large body of previous research explains that, on the one hand, financial development affects TFP growth and on the other, a financial crisis adversely affects TFP. A factor that remains under-investigated in assessing the relation of financial development and economic growth/crisis is the allocation of financial resources to different types of investments. Our intention is to expand the work of De Long et al. (1992) and De Long and Summers (1991) who explain the diverse impact of investment in property and investment in equipment on GDP growth, total factor productivity (TFP) growth and social returns. While these studies do distinguish between different types of investment, they do not consider the role of finance, which is the area we intend to explore with our work. 
Research that explores the links between finance and economic development/crisis can be grouped in two major themes: the "finance-led" growth (and crisis) approach, and the "structural roots" approach.

The "finance led" approach has its origins in Schumpeter's seminal work on the prudent intermediary. He argues that financial agents acquire and evaluate information on firms and investment projects, and in doing so they allocate credit to the most productive uses (Schumpeter, 1934). This idea has been developed further into the concept of the financial institutions as delegated monitors (Diamond, 1984), i.e. actors who deal with risk and promote growth by mobilizing and optimally allocating financial resources (savings) in an efficient and productive manner. According to this approach, the financial system may play a very important role in supporting the economic development by granting good firms and good projects the access to the finance they need (for an overview of the finance-growth nexus pre-mid 1990's era see Levine (2005)). Building on the framework provided by Barro (1991), King and Lavine (1993), are among the first to show empirically that financial development promotes long-run growth in terms of GDP implicitly supporting Schumpeter's theory. The nexus is also confirmed by research based on microeconomic data at industry and firm level, that shows that in more financially developed countries, finance dependent industries grow faster (Rajan and Zingales, 1998; Wurgler, 2000). Interestingly, higher ratios of total private sector credit to GDP are also found to have a positive impact on total factor productivity growth and ultimately on GDP growth suggesting a positive effect of increased household access to finance (and consumption) on economic growth (Beck et al., 2000). Financial development, understood as new and more efficient financial system, is also found to affect growth through both the channels of investment and capital accumulation (Benhabib and Spiegel, 2000) and improved productivity (Calderón 
and Liu, 2003). In fact, previous research challenges such a simplified role of financial deepening, arguing that there are thresholds in terms of financial deepening that benefit society in terms of economic growth and inequality reduction (Kose et al., 2011). Along this line, recent research on Europe suggests that financial development may also reduce inequality by supporting economic development: countries with more developed financial markets (financial deepening) are found to reach greater levels of social equality, at relatively lower income levels, compared to countries with less developed financial systems (Baiardi and Morana, 2018, 2016). Research additionally suggests that the legal system and regulation influence the use of finance (La Porta et al., 1998, 1997; Moro et al., 2016): the financial standardization between the EU-15 member States positively affected output growth through the increased efficiency of financial intermediation until 2001 (Galindo et al., 2007) while banking harmonization improved bank portfolios and credit allocation. However, the positive relationship between finance and growth (the "financial-led" growth) is challenged by indications of a link between financial liberalization and banking crises (Kaminsky and Reinhart, 1999): excessive debt linked to greater liberalization may cause financial instability leading to a historical pattern of boom and bust cycles (Jordà et al., 2016; Reinhart and Rogoff, 2009). Relatively recent empirical evidence suggests a vanishing and eventually detrimental effect of finance on growth. For instance, Rousseau and Wachtel (2011) provide support to King and Levine's results for period 1960-1989 (King and Lavine, 1993) but they also stress that the positive effect of financial depth on growth vanishes completely for the subsequent period of 1990-2004. This evidence raises questions about whether financial liberalization may inhibit rather than assure a sustainable GDP growth through the finance-entrepreneurship-innovation process. Haiss et al. (2016) provide evidence that financial intermediation (the part of the economy that is concerned with buying and selling 
on the financial markets) in Europe has been detached from the real sector (the part of the economy that is concerned with producing goods and services) adversely affecting growth. Narayan and Narayan (2013) find, that bank credit has a negative effect on short-run growth for both a panel of 65 developing countries and a subset of European countries for the period of 1995-2011. However, research fails to find support for the bank-led growth hypothesis for a panel including the EU 26 member states for the period of 1999-2012 (Georgantopoulos et al., 2015). The conflicting evidence is in some way reconciled by more recent research that suggests the existence of a threshold above which finance is irrelevant or even detrimental to growth and show an inverted U-shaped relationship between private sector credit and GDP (Arcand et al., 2015; Cecchetti and Kharroubi, 2012). Furthermore, in the case of European countries the inverted U-shaped relationship is more pronounced for the years right after 1999 (Arcand et al., 2015). These findings are also supported by evidence on Central and Eastern Europe where rapid credit expansion is found to be linked to macroeconomic imbalances such as current account deficits, inflationary pressures and asset bubbles (Coudert and Pouvelle, 2010).

The structural roots approach stresses the importance of exploring the role of credit access at disaggregated level: growth (and crisis) does not depend on the amount of finance or on the financial innovation. Relevant factors are the behaviour of different actors (households vs firms), how much finance is allocated to them, the reasons why it is allocated to them, how they use it and how it stimulates the economic growth and avoid crisis (Caporale et al., 2015; Mian and Sufi, 2014). Empirical research shows the diverse effects of household lending vs firm's lending on GDP growth (Beck et al., 2012), on the trade balance (Büyükkarabacak and Krause, 2009), and on banking crises (Büyükkarabacak and Valev, 2010). By looking at 10 new EU members for the period 1994-2007, Caporale et al. (2015) show that productive capital 
accumulation is the best determinant for growth implying that it is mandatory for the financial system to provide support to firms since they are the drivers for capital accumulation. The growth enhancing route between finance, productive capital and GDP growth is also found by Leblebicioğlu and Madariaga (2015) who provide evidence of financial flows and financial development on GDP growth through the composition of capital. Interestingly enough, irrespective of the importance of allocating finance to capital accumulation, the financial institutions seem to move in the opposite direction: approximately two thirds of the typical banks' business consist of household lending for real estate purposes to the point that "housing finance has come to play a central role in the modern macro economy" (Jordà et al., 2016). The proportion is definitely larger than one third at the beginning of the $20^{\text {th }}$ century. The increase may be possibly linked to the fact that in the pre-crisis period the practice of credit allocation was progressively dissociated from household income standards (Mian and Sufi, 2014) to the point that lending to households was provided without properly considering their income and assets. However, it can also depend on the regulatory element (Basel agreements) that stresses the importance of risk management and pushes banks to allocate finance towards low risk investments (households' mortgages are lower risk than firms' loans). The result is a pre-crisis growth characterized by limited productive investment and stationary wages, as suggested by the declining shares of real household income over GDP aggravated by uneven income distribution since the lowest income quintiles have the greatest marginal propensity to consume (Barba and Pivetti, 2009; Fitoussi and Saraceno, 2010; Stiglitz et al., 2009; Tridico, 2012). In such a context, it is not a surprise that household leverage is found to be a good predictor for the US and European financial crisis and subsequent recessions (Glick and Lansing, 2010, 2009; Mian and Sufi, 2009; Mian et al., 2013). Caporale et al. (2015) have merit when, by stressing the current 
account imbalances, they argue for policies to slow down household credit and encourage better allocation of credit to productive investments. All in all, the structural roots approach brings into question the long-term sustainability of an economic system which moves away from productive and income generating investment and relies on leveraging stable incomes to achieve growing GDP. It stresses the negative effect of growth that is obtained via loose credit in a low growth economy instead of economic expansion obtained by real household income growth that is a consequence of financing productive investments (Summers, 2014).

Looking jointly at both the structural roots approach and the finance-led growth approach, research suggests that excessive finance allocated to household may have a detrimental effect on productive investment, and specifically on the growth of the stock of fixed capital resulting into reduced household economic welfare and income (Jappelli and Pagano, 1994). The adverse effect may be amplified by two additional factors: diminishing total factor productivity which relies on an unsound expansion of fixed capital (Caselli and Wilson, 2004; De Long et al., 1992; De Long and Summers, 1991), and reduction in employment and real wage levels determined by the pace and quality of capital formation (Arestis et al., 2007). Thus, both the decisions about the amount/innovation of credit (finance-led approach) and the way in which it is allocated between households vs. firms by the financial intermediary sector (structural root) may play a key role in determining whether credit will assume its economic function as per the Schumpeterian premise or it will lead to an unsustainable finance-led growth uncorrelated to household income and productive investment.

Our analysis focuses on exploring whether financial intermediaries allocated the financial resources in such a way that they created a fixed capital formation which was not productive enough to generate the income to pay for the debt created. Thus, we explore whether a capital 
formation that is weighted towards residential construction, and financed through household lending, promotes unsustainable GDP growth. Our analysis explores whether the mentioned process and the related excessive household leverage has a direct "crowding out" effect on fixed capital formation, via which it causes a GDP growth decoupled from real household income.

\section{Sample Description and Variables}

Our sample consists of the cross-section of 26 European countries for the period 19952008 thus covering the period leading up to the financial crisis of $2008^{1}$. For each country-year observation we collect data from the publicly available Eurostat database. We construct a number of variables as proxies of economic growth, capital composition and financial development and use these variables on econometric specifications.

\subsection{Dependent and Independent Variables}

Our dependent variable is INC2GDP defined as the ratio of real household net disposable income per capita (household final consumption expenditure and savings) to real GDP per capita in the next period in relation to the same quantity in the previous period

$$
I N C 2 G D P=\frac{\frac{\text { Household Net Disposable Income }_{(t+1)}}{G D P_{(t+1)}}}{\frac{\text { Household Net Disposable Income }_{(t)}}{G D P_{(}(t)}}-1
$$

The ratio can be interpreted as the speed (and direction) at which the economy is able to make GDP disposable to the households in the form of net disposable income. When the ratio is greater than 0 , it indicates an increase in households' wealth: the households' income in relation to the GDP in the next period is greater that the household income in relation to the GDP of the previous one. Thus, households are, economically speaking, better off in the sense that they

\footnotetext{
${ }^{1}$ In untubulated results we extend tests for the sample covering the period 1995-2012
} 
receive a higher proportion of the GDP. At the same time, when the ratio is negative, households' income in relation to the GDP in the next period is lower with respect the previous period. This means that households benefit only marginally from the growth in the GDP and that the "quota" of the GDP that is transferred onto them decreased. This metric is also a good proxy of sustainable economic growth. In fact, as long as the ratio is stable around 0 or positive, there is an alignment between GDP growth and households' economic growth: GDP grows and the increased wealth moves onto the households that are able to spend and invest supporting further the economy. In other words, a trend in the ratio with values above zero suggests that the economy is enjoying an organic and sustainable growth. At the same time a value of the ratio below 0 implies a divergence of household income growth and GDP growth meaning a decoupling of GDP growth from the households' income growth. This suggests that GDP's growth is only fractionally transferred onto households and their capability to spend and invest extra income in order to support further the economy is at least partially compromised. A trend with ratios systematically below 0 reveals a divergent path between income and GDP, which is deemed as an indication of an unbalanced and unsustainable growth (Barba and Pivetti, 2009; Stiglitz et al., 2009).

We have a battery of independent variables that we expect to impact on our dependent variable. HOUSECAP is defined as the growth of residential construction as a percentage of gross fixed capital formation.

$$
\text { HOUSECAP }=\frac{\frac{\text { Residential Construction }_{(t+1)}}{\text { FIxed Capital }_{(t+1)}}}{\frac{\text { Residential Construction }_{(t)}}{\text { Fixed Capital }_{(t)}}}-1
$$

It captures the speed at which the residential construction is expanding with respect to all other kinds of fixed capital formation, possibly "crowding-out" investments in fixed assets, 
particularly investment in productive fixed capital linked to increases in household welfare (De Long et al., 1992; De Long and Summers, 1991), wages and employment (Arestis et al., 2007). If the ratio is above 0 it means that residential construction is growing faster than fixed capital while if it is below 0 , it means that its growth is slower than fixed capital. FIXEDASSETS is defined as the growth of the sum of buildings other than residential construction (i.e. commercial and industry), machines and equipment, equipment related to information and communication technology, intellectual property products and biological resources as a percentage of total gross fixed capital formation.

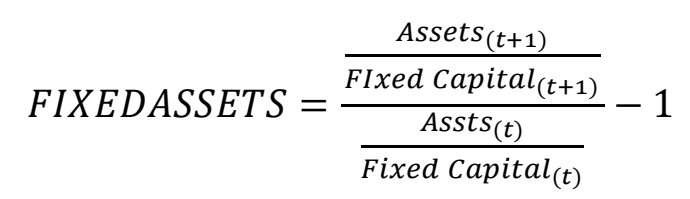

This ratio captures the speed at which the investment in productive assets is expanding with respect to all types of fixed capital. HHLEVERAGE (i.e. household leverage) is the growth rate of the ratio between household loans and household gross disposable income defined as the amount of money that individuals (i.e. the household) have available for spending or saving. It is important to point out that this variable is based on household gross disposable income while INC2GDP is based on real household net disposable income.

$$
\text { HHLEVERAGE }=\frac{\frac{\text { Household Loans }_{(t+1)}}{\text { Household Gross Disposable Income }_{(t+1)}}}{\frac{\text { Household Loans }_{(t)}}{\text { Household Gross Disposable Income }_{(t)}}}-1
$$

This ratio explains whether households are expanding their dependence on debt finance with respect to their income and thus it can be easily interpreted as an indicator of financial fragility: positive $H H L E V E R A G E$ is associated with a higher proportion of income that has to be used to repay loans. Thus, it grasps both the risks of excessive financial allocation towards households and the financial risk linked to static wages. To capture the allocation of financial 
resources towards investments and income generating activities, we use CORPDEBT (i.e. debt of firms excluding the financial institutions), equal to the growth of the ratio of firms' loans to GDP.

$$
\operatorname{CORPDEBT}=\frac{\frac{\operatorname{Firms~Loans}_{(t+1)}}{G D P_{(t+1)}}}{\frac{\operatorname{Firms~Loans}_{(t)}}{G D P_{(t)}}}-1
$$

The ratio can be interpreted as the support to firms provided by the financial system, i.e. strong support through granting expanding credit (above 0 ) or weak support by constraining credit (below 0). Finally, in order to account for the overall availability of credit at system level, we use the growth rate of the yearly flow of new credit as a ratio of GDP (NCREDIT).

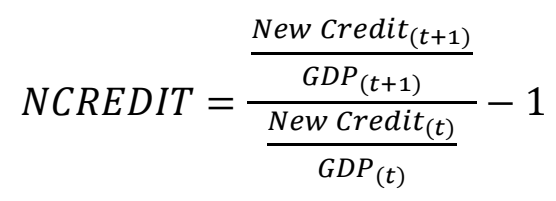

This variable measures the speed at which additional (new) credit issued is added to the stock of loans.

\subsection{Controls}

Based on models of endogenous growth (Barro, 1991) the empirical literature on financegrowth has included several control variables which are known to affect economic growth such as GDP, household income and fixed capital formation (for an overview see Beck et al. (2008). In our specifications we include inflation (INFLATION), trade openness defined as imports plus exports (TRADE), human capital as the average years of schooling (HUMANCAPITAL), government expenditure scaled by GDP (GOVERNMENT) and the growth of the labour force measured by the sum of unemployed and the employed (LABOUR).

\section{Descriptive Statistics}


A set of descriptive statistics is reported in tables 1 and 2 giving distributional properties of each variable as well as a first glimpse of their possible interactions.

\section{INSERT TABLE 1}

Looking at $I N C 2 G D P$ (table 1), our data shows a marked divergence of income growth and GDP growth in the years leading up to the recession in 24 out of 26 countries in the sample. Only two countries showed convergence, with four countries showing divergence between $1 \%$ and $10 \%$, five countries between $11 \%$ and $30 \%$, nine countries between $31 \%$ and $60 \%$ and six countries above $61 \%$ (with the greatest divergence being at $167 \%$ ).

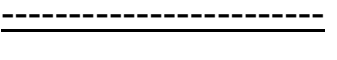

\section{INSERT TABLE 2}

Table 2 shows that on average INC2GDP (indicating whether the proportion of GDP as a net income for families increases or decreases between two subsequent periods) is negative at an average annual rate of $-0.75 \%$, for the period $1995-2007$. The value suggests that households are not better off since the proportion of GDP that is transformed in net disposable income decreases on average during the period. Thus, GDP growth was unbalanced and unsustainable on the long run.

Our aggregated proxy for average yearly new credit to the economy (NCREDIT) shows a quite rapid growth at an annual rate of $13.30 \%$. Interestingly, HHLEVERAGE grows by an annual average of $11.70 \%$ whereas loans to firms' (CORPDEBT), grows by $4.40 \%$ per year. This suggests that the financial intermediary sector allocates financial resources mostly to households 
instead of firms. The divergence between GDP growth and household income on one hand and of household leverage and firm debt on the other suggests similar divergence within the formation of fixed capital. Interestingly, table 2 shows that on average residential construction crowds-out fixed capital (e.g. information and communication technology, intellectual property products and machinery) by an annual rate of around 3\%: total fixed capital formation as a percentage of GDP grew by $2.23 \%$ per annum (boosting GDP growth). However, this is led by residential construction instead of productive investments. In fact, FIXEDASSETS, the set of assets relating to production and innovation, shows a negative average growth of $-0.50 \%$ as a ratio of gross fixed capital formation. The evidence suggests a fixed capital formation growth based on residential construction instead of productive investments. This aspect may be linked to the strategies in terms of capital allocation pursued by the financial system. It could be claimed that property is structurally highly correlated with household leverage since household leverage largely overlaps with mortgage related lending. However, this does not necessarily imply a systematic increase of housing as a portion of the total capital formation of an economy. Any systematic increase in HOUSECAP in conjunction with a systematic decrease in FIXEDASSETS signals an increasing risk for the future income of households (Arestis et al., 2007; Jappelli and Pagano, 1994; Turner, 2015). The statistics provide indications towards the premise that increase in household leverage could have an adverse effect on productive investment, in particular the growth of the stock of fixed capital which in turn negatively affects household economic welfare and income (Jappelli et al., 2005; Turner, 2015).

\section{Results}


We start our testing by firstly examining the effects of financial development on the divergence between household income growth and GDP. Our base specification consists of a dynamic panel model with lagged dependent variable. Alternative econometric techniques can be used to implement our analysis. Previous research suggests that OLS estimators on lagged dependent variables in dynamic panel models are biased (Baltagi, 2008). This is discussed extensively in relatively recent papers by Huang and Ritter (2009) as well as by Flannery and Hankins (2013) who assess the efficacy of GMM-type estimators in comparison to OLS, establishing the superiority of these estimators. We likewise refrain from presenting the analysis based on OLS and rely on GMM-type estimators for the following regression:

$$
\begin{aligned}
& I N C 2 G D P_{i, t}=\alpha+\beta_{0} I N C 2 G D P_{i, t-1}+\beta_{1}\left(\operatorname{HHLEVERAGE}_{i, t}\right)+\beta_{2}\left(\operatorname{CORPDEBT}_{i, t}\right)+ \\
& \beta_{3}\left(\operatorname{NEWCREDIT}_{i, t}\right)+\beta_{4}\left(\operatorname{INFLATION}_{i, t}\right)+\beta_{5}\left(\operatorname{TRADE}_{i, t}\right)+\beta_{6}\left(\operatorname{HCAPITAL}_{i, t}\right)+ \\
& \beta_{7}\left(\operatorname{GOVERNMENT}_{i, t}\right)+\beta_{8}\left(\operatorname{LABOUR}_{i, t}\right)+\varphi_{t}+\vartheta_{i}+\varepsilon_{i, t}
\end{aligned}
$$

All variables are measured in year $t$ for country $i$, with $I N C 2 G D P_{i, t-1}$ representing the lag-dependent variable in the dynamic panel model specification. The terms $\varphi_{t}$ and $\vartheta_{i}$ capture time-specific and country-specific effects respectively which are present in the panel data. Our model is subject to endogeneity in the sense that the pronounced relationship between the explained variable and the explanatory variables could be affected by reverse causality or/and simultaneity. Furthermore, persistence in growth rates and the inclusion of the lag-dependent variable (INC2 $\left.\mathrm{GDP}_{\mathrm{i}, \mathrm{t}-1}\right)$ are likely to induce serial autocorrelation while time invariant crosscountry effects make our results subject to heterogeneity. To address these issues in line with 
finance-growth literature (Beck et al., 2000; Calderón and Liu, 2003; Narayan and Narayan, 2013; Rousseau and Wachtel, 2011) we initially employ a First-Differencing GMM methodology in which lagged-transformed explanatory variables are used as valid instruments (Arellano and Bond., 1991). While contemporaneous levels of the explanatory variables may be correlated with the error term, their lagged values, conditional on other covariates, could be independent from the error term due to a delay in the actualization of the contemporary dependent variable caused by changes in the explanatory factors. The issue of autocorrelation is likely addressed by instrumenting the lagged dependent variable with its past levels. To remove fixed effects, we transform the regressors by first taking differences because country-specific effects are assumed to be time-invariant. Alternatively, we transform lagged variables by the method of orthogonal deviations (Arellano and Bover, 1995), which has the advantage of preserving data points in samples with time gaps. The method of orthogonal deviations is forward looking since instead of subtracting the one-lagged observation from the current one to get the "difference", it subtracts the mean of all future available observations. Hence meaningful "differences" are available for all but the last observation, regardless of time gaps. We control the proliferation of instruments by specifying the number of lags used in the set of instruments to 2 and report relevant tests of serial autocorrelation and overidentification. Our results confirm that serial autocorrelation is present at the $1^{\text {st }}$ lag but vanishes at the $2^{\text {nd }}$ lag. Our tests uniformly pass the Hansen test of overidentification.

Further to our "base-model" estimation we undertake the following robustness tests: first, we re-estimate equation 1 by adding the legal origin of country as an additional external instrument. The legal origin of each country is used to control for simultaneity bias by extracting the exogenous component of financial intermediation development. The notion of legal origin as 
a valid instrument rests on the idea that most countries have obtained their legal systems through "occupation" and therefore legal systems are exogenous to the development of country financial intermediation. Moreover, since legal origin defines the contracting environment, which in turn defines issues such as the rights of creditors, enforcement of debt contracts etc., it helps to account for cross-country differences of financial intermediation development (La Porta et al., 1998; Levine, 1999; Moro et al., 2016). Following Beck et al. (2000) we classify countries as having either English, French, German or Scandinavian legal origin ${ }^{2}$.

Second, we employ two alternative dynamic panel estimators (with and without the legal origin as external instrument). The first alternative is a System GMM (or SGMM) estimator with Arellano/Bond-type instruments (Blundell and Bond, 1998). The SGMM method presents the advantage of increased efficiency using a system of equations, one differenced and one in levels, to account for the case in which lagged regressors are poor instruments for the first-difference equation. At the same time the SGMM generates a greater number of instruments using both lagged-differences and lagged-levels with the penalty of potential overidentification. To that end we report the Hansen test of overidentification and the number of instruments. The second alternative is the Long Difference Estimator (Hahn et al., 2007) which accounts for higher orders of serial correlation. We follow Huang and Ritter (2009) in providing a Long Difference Estimator with 4 lags and 3 iterations (in which residuals from the first 2-passes are also employed as instruments). In all our robustness tests results remain qualitatively unchanged.

Table 3 presents the results of model 1 estimated with the Difference-GMM method. In columns (I)-(VI) we run the model "piecewise", starting with a minimum of the three explanatory variables (plus the lagged dependent variable) and progressively adding controls up

${ }^{2} \mathrm{~A}$ fifth classification of Socialist legal origin is not present in our dataset. 
to the full specification. This approach allows to examine the robustness of the results: if the results are robust when additional controls are added, we can derive that the effect of the explanatory variables is stable.

\section{INSERT TABLE 3}

The output shows that household leverage growth (HHLEVERAGE) and new yearly total private sector credit growth (NCREDIT) are negatively related to INC2GDP and consistently statistically significant at $1 \%$ throughout the regressions. This implies that an expansion of credit in general (i.e. NCREDIT) as well as the increase in household leverage to finance the acquisition of non-productive assets (HHLEVERAGE), have a negative impact on household economic growth. In other words, credit expansion (financial led approach) as well as credit expansion to households to buy non-productive assets (structural root approach) makes the households worse off in the sense that they receive a decreasing quota of the GDP that, in turn, represents a biased and unbalanced growth that can trigger an economic downturn. At the same time the increase of the proportion of credit given to the firm (CORPDEBT) is positively related to $I N C 2 G D P$ and almost everywhere statistically significant at a $10 \%$ level. This suggests that the expansion of credit used to buy productive assets makes households better off as they may enjoy an increase in their income that is greater than the increase of the GDP. This also implies a coherent and balanced growth for the economy.

The results are robust to the inclusion of a number of control variables. Our tests reveal strong $1^{\text {st }}$ order autocorrelation (AR (I) tests) however residual autocorrelation vanishes at the $2^{\text {nd }}$ 
lag (AR(II)). Robust standard errors are corrected. The Hansen $\chi^{2}$ statistic satisfies the criterion of overidentification.

Table 4 presents the robustness tests with regards to alternative dynamic-panel estimators and the addition of legal origin as an external instrument.

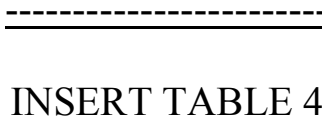

INSERT TABLE 4

Panels A, B and C correspond to the Difference-GMM, SGMM and the Long

Differencing Estimator. Looking at the results of the SGMM estimator we note that the increased number of instruments may result into a weaken Hansen test. In un-tabulated results we reestimate the specification with collapsed instruments. Our results are qualitatively identical. Columns (I) in all panels omit the inclusion of legal origin as an external instrument while it is included in Columns (II) in all panels. In all our robustness tests results remain consistent, with HHLEVERAGE and NCREDIT exerting a negative and statistically strongly significant effect to INC2GDP and CORPDEBT exerting a positive and statistically significant effect on INC2GDP.

Our findings support the view that specific financial intermediation practices, namely the allocation of financial resources to households instead of firms, stimulate the phenomenon of the decoupling of the household income with respect to GDP growth (diverging household income/GDP growth). This emerges by looking at the negative effects of household leverage growth and yearly new credit growth on the INC2GDP ratio. By contrast, firms' debt exhibits a positive effect towards convergence, leading to a balanced and sustainable growth. Elaborating on the results of the full model in table 3 a negative effect of HHLEVERAGE of at least -0.0890 can be seen when all other factors are held constant. Likewise, the same increase in firms' debt 
(CORPDEBT), it yields a positive effect on INC2GDP of 0.0290 . This means that in the years of credit expansion preceding the crisis, firms' debt growth played a mitigating role. However, it was not sufficient to support household income economic growth since the adverse effects of allocation of credit towards households exceeded the benefits of productive debt. As such the total private sector credit (NCREDIT) eventually exerted a negative effect of -0.0070 on the $I N C 2 G D P$ ratio.

\subsection{Split Regressions}

The sample, comprising of 26 countries, is clearly subject to heterogeneity. While we control for cross-country fixed effects through a difference-model and account for cross-country differences of financial intermediary development through the inclusion of legal origin as an exogenous instrumental variable, it is useful to assess whether our results are more strongly pronounced in certain countries. To that end we generate three sample partitions where countries are grouped according to be above or below the median value and run split regressions for the full specification of equation 1 . Table 5 gives the results.

\section{INSERT TABLE 5}

The first partition (Panel A) distinguishes between high/low GDP growth per year countries. Although the pre-crisis years have been signified by high GDP growth across all European countries, the average growth rates vary significantly, especially between the Eastern and the Western European economies. Eastern European economies experienced on average higher GDP growth than the Western European countries. The coefficient of HHLEVERAGE for the lower growth countries $(-0.2020)$ is nearly twice that of the higher growth countries $(-0.1100)$ 
and the result is statistically significant at $1 \%$. Moreover, CORPDEBT for the higher growth countries becomes statistically insignificant while the coefficient for the lower growth countries remains significant. This indicates that both the negative effects of household leverage and positive effects of firms' debt are larger in countries/years were GDP growth is below the median of the all-country sample.

To confirm these effects of financial development on the more developed economies we re-test further our model on two additional partitions. Firstly, we distinguish countries according to their initial levels of household leverage. Then we separate the countries according to whether they have adopted the Euro or not (Panel C). In order to capture the long-term effects of financial liberalization due to the Euro membership, our partition is between countries which joined the Euro in 1999 versus the countries joining the Euro in any later year.

In the case of the initial level of HHLEVERAGE (panel B), the negative effect on INC2GDP is much more significant for the countries with a higher initial level of household leverage (coefficient -0.2000 ) at the $1 \%$ level) compared to countries with lower initial household leverage (coefficient -0.1120 at the $1 \%$ level). Moreover, CORPDEBT is statistically not significant for the countries with low initial levels of household leverage, whereas for the others it becomes statistically significant at the $5 \%$ level.

Regarding countries which joined the Euro in 1999, the evidence shows that the effect of HHLEVERAGE is far greater for those that joined the Eurozone in 1999 (coefficient -0.1600 and statistically significant at $1 \%$ ) compared to the effect observed for the countries that joined the Eurozone in later years (coefficient -0.1100 and statistically significant at $1 \%$ ). Moreover, the coefficient of CORPDEBT for the countries adopting the Euro in 1999 becomes significant at the $5 \%$ level while the same coefficient becomes not significant for the countries that joined the 
Eurozone in later years. This is in line with Arcand et al. (2015) who find that the inverted Ushaped relationship of finance on growth is more pronounced in Europe following the 1999 inception of the Euro due to the corresponding financial liberalization.

\subsection{Transmission Channels}

We now try to determine the channels through which greater leverage may generate a divergence of household income growth and GDP growth. In particular, we explore whether household leverage may affect the composition of total fixed formation and thus lead to a GDP growth decoupled from real-household income in line with the theory that increased household leverage might negatively affect productive investment with repercussions on growth of fixed capital formation and subsequent adverse effects on household welfare (Jappelli and Pagano, 1994), and with the evidence that the composition of capital matters for employment and wages (Arestis et al., 2007). To account for the expansion in housing and its effects on the composition of capital we have constructed the variable HOUSECAP, i.e. the growth of residential construction as a percentage of gross fixed capital formation. Likewise, to capture the productive component of capital formation we have introduced FIXEDASSETS. A “crowding-out" effect implies that HHLEVERAGE should be positively related to HOUSECAP. In addition, the "crowding-out" suggests a direct negative effect of HOUSECAP on INC2GDP, and hence an indirect negative effect of HHLEVERAGE on INC2GDP via HOUSECAP.

The indirect association on INC2GDP by HOUSECAP via finance can be best formulated in a 2 stage least squares system with fixed effects (2LS-FE). Similarly to Leblebicioğlu and Madariaga (2015), we estimate simultaneous regressions in which the first stage LS regresses HOUSECAP on finance variables (HHLEVERAGE, CORPDET, NCREDIT) and in turn the second stage LS regresses INC2GDP on HOUSECAP. As such, HOUSECAP is instrumented on 
HHLEVERAGE, CORPDEBT and NCREDIT. In both stages of the simultaneous regression we retain the same vector of control variables as explained in equation 1.

Formally we estimate the following simultaneous regressions:

$$
\begin{aligned}
& {\operatorname{INC} 2 G D P_{i, t}}=\beta_{0}+\beta_{1}\left(\operatorname{HOUSECAP}_{i, t}\right)+\gamma\left(\operatorname{CONTROLS}_{i, t}\right)+\varphi_{t}+\vartheta_{i}+\varepsilon_{i, t} \\
& \operatorname{HOUSECAP}_{i, t}=\alpha_{0}+\alpha_{1}\left(\operatorname{HHLEVERAGE}_{i, t}\right)+\alpha_{2}\left(\operatorname{CORPDEBT}_{i, t}\right)+\alpha_{3}\left(\operatorname{NCREDIT}_{i, t}\right)+ \\
& \gamma^{\prime}\left(\operatorname{CONTROLS}_{i, t}\right)+\varphi_{t}+\vartheta_{i}+\varepsilon_{i, t}
\end{aligned}
$$

The model above explores the link between INC2GDP and household debt. In order to explore the analogous effects on INC2GDP by FIXEDASSETS via finance we estimate the following simultaneous regression where the variable HOUSCECAP is substituted by the variable FIXASSETS

$$
\begin{aligned}
& \operatorname{INC}_{2} G D P_{i, t}=\beta_{0}+\beta_{1}\left(\operatorname{FIXEDCAP}_{i, t}\right)+\dot{\gamma}\left(\operatorname{CONTROLS}_{i, t}\right)+\varphi_{t}+\vartheta_{i}+\varepsilon_{i, t} \\
& \operatorname{FIXEDCAP}_{i, t}=\alpha_{0}+\alpha_{1}\left(\operatorname{HHLEVERAGE}_{i, t}\right)+\alpha_{2}\left(\operatorname{CORPDEBT}_{i, t}\right)+\alpha_{3}\left(\operatorname{NCREDIT}_{i, t}\right)+ \\
& \gamma^{\prime}\left(\operatorname{CONTROLS}_{i, t}\right)+\varphi_{t}+\vartheta_{i}+\varepsilon_{i, t}
\end{aligned}
$$

Finally, to capture the combined effect of HOUSECAP and FIXEDASSETS on INC2GDP we estimate:

\footnotetext{
${ }^{3}$ Equation 2a is analogous to equation 1. Because the lagged INC2GDP in our base results is nowhere significant and to avoid issues of serial correlation in the FE2SLS the variable is simply omitted.
} 
$\operatorname{INC}_{2 G D P_{i, t}}=\beta_{0}+\beta_{1}\left(\operatorname{HOUSECAP}_{i, t}\right)+\beta_{21}\left(\operatorname{FIXEDCAP}_{i, t}\right)+\gamma\left(\operatorname{CONTROLS}_{i, t}\right)+\varphi_{t}+\vartheta_{i}+$ $\varepsilon_{i, t}$

where HOUSECAP and FIXEDASSETS are instrumented as in $2 \mathrm{~b}$ and $3 \mathrm{~b}$. Table 6 reports the results.

\section{INSERT TABLE 6}

Column (I) shows the effect of HOUSECAP on INC2GDP whereas HOUSECAP is instrumented on the finance variables. From the $1^{\text {st }}$ stage regression $(2 b)$ we obtain that the strongest and more statistically significant effect on HOUSECAP comes, as expected, from HHLEVERAGE. We therefore also include in our results the indirect effect of HHLEVERAGE on INC2GDP obtained as $\hat{\beta}_{1} x \hat{\alpha}_{1}$ (eq. $\left.2 \mathrm{a}, \mathrm{b}\right)$. The indirect effect can be understood considering that: a) $\hat{\alpha}_{1}$ represents the impact of HHLEVERAGE produced on the first-stage regression (2b), and b) $\hat{\beta}_{1}$ represents the impact of the fitted value of FIXEDCAP on INC2GDP captured in the second stage regression (2a). Likewise, column (II) shows the effect of FIXEDASSETS on INC2GDP while column (III) shows the combined effect of FIXEDASSETS and HOUSECAP (the indirect effects of HHLEVERAGE are not repeated for clarity of exposition).

The results show that HOUSECAP has a significant negative effect of -0.3880 on INC2GDP at $1 \%$ statistical significance level. The interpretation of the indirect effect is subtler: first since the indirect effect is calculated as HOUSECAP over INC2GDP times HHLEVERAGE over HOUSECAP and since the former is found to be -0.3880 it directly follows that the coefficient of HHLEVERAGE over HOUSECAP is 0.2440 . Hence, HHLEVERAGE is positively 
related to HOUSECAP suggesting a diversion of credit towards residential construction and unproportionately away from productive investments. An increase in $H H L E V E R A G E$ results in an increase of 0.2440 in HOUSECAP which in turn promotes a reduction in INC2GDP (unbalanced growth) of -0.0950 .

The results indicate a "crowding-out" effect where household leverage causes the phenomenon of an increasing overall fixed capital formation characterized by an increasing share of residential construction and decreasing share of productive assets. This finding is reinforced when we look at FIXEDASSETS as the pipeline through which HHELEVERAGE exerts an effect on INC2GDP. Specifically, the results show that FIXEDASSETS has a significant positive effect of 1.177 on INC2GDP at $1 \%$ statistical significance level, while the indirect effect of HHLEVERAGE through FIXEDASSETS remains negative. Analogously to the indirect effect of HHLEVERAGE/HOUSECAP, we can infer that the coefficient of HHLEVERAGE over FIXEDASSETS is negative and equal to -0.0290. Hence an increase in HHLEVERAGE decreases FIXEDASSETS by -.0290 which in turn decreases INC2GDP by -0.0350 .

All in all, our results suggest that household leverage for the years during the financial expansion exerts a negative effect on sustainable economic growth through capital formation and specifically by distorting the composition of capital: the increased household leverage drives investments to unproductive assets (i.e. private properties).

\subsection{Marginal Analysis}

The importance of the relationships between household leverage, the composition of fixed capital and sustainable growth can be further illustrated by looking at the comparative data and corresponding marginal effects analysis (table 7) between the five European countries with the slowest annual growth in household leverage (cluster A) and the countries with the fastest 
growth in household leverage (cluster B) during the years of the financial boom preceding the $2007 / 2008$ crash.

\section{INSERT TABLE 7}

The mean annual growth in household leverage of cluster A is on average 0.0250 per annum whereas the mean annual growth in household leverage for cluster B is 0.3020 . Based on our preceding analysis it comes not at surprise that the corresponding INC2GDP for clusters A and $\mathrm{B}$ is -0.0039 (low leverage growth) vs -0.0120 (high leverage growth), HOUSECAP is 0.0006 (low leverage growth) 0.0700 (high leverage growth) and FIXEDASSETS is 0.0018 (low leverage growth) vs -0.0116 (high leverage growth).

What emerges is that countries with a moderate household leverage growth has a near parallel growth of household income to GDP ratio as well as a near parallel growth of the capital formation of productive assets and residential construction. On the other hand, countries with a high household leverage growth, show an unbalanced and unsustainable economic growth and capital formation growth. In the case of capital formation residential construction is growing much faster than the productive assets, and in the case of economic growth household income is diverging significantly from GDP growth.

To explore the policy implications of our findings, we conduct a marginal effects analysis based on our regression results and the actual country data. Column (I) illustrates the indirect negative effects household leverage has on a household income growth through the significant "crowding-out" effect it exerts on productive assets. Specifically, we observe that in the case household leverage of cluster B to converge to cluster A, all other things equal, GDP growth 
would have been driven by household income growth to a greater extent, since the ratio between the two would have turned from a negative of -0.0120 to a positive 0.0143 . Moving on to column (II) we see the direct impact of residential construction taking over fixed capital formation while instrumented on financial development. Specifically, all other things being equal, if fixed capital formation growth were not driven by residential construction at the annual pace of 0.0700 , but instead capital formation growth was based on the parallel growths of productive assets and residential construction (HOUSECAP growth of -0.06 suggests that both residential construction and productive assets are growing at almost the same pace with a marginal difference in favour of the formation of productive assets), then household income would be on a converging path to GDP growth of 0.0118 per annum rather than the diverging of -0.0120 per annum. In line with this, we see from column (III) that for cluster B, household leverage was driving down the share of productive assets to total assets by -0.0116 each year, whereas in the countries with moderate growth of household leverage productive assets were moving together with residential construction in boosting overall capital formation (with a slight lead by productive assets formation of 0.0018 per year). In the case that cluster B would have converged from -0.0116 to 0.0018 , all other things equal, then GDP growth would be in a correlated converging path to household income at a yearly rate of 0.0037 , instead of the factual yearly diverging path of 0.0120 .

\section{Discussion}

Previous research explored the links between finance and economic development/crisis and proposes two major themes: the "finance-led" growth (and crisis) approach and the 
"structural roots" approach. We argue that both approaches have their own merits and that they are not necessarily mutually excluding.

We find that the pure expansion of the credit does not support a balanced economic expansion ("finance-led" approach). If anything, it tends to amplify the decoupling between GDP growth and households' income growth at the expenses of the latter. However, this is not the entire story. Our results show the mechanism behind the growth which preceded the financial crisis: it is characterized by lack of productive investment (Barba and Pivetti, 2009; Wisman, 2013) suggesting that lending and leverage are not the simple cause since what matters is also who is leveraging and what they are leveraging for (structural roots approach). We show that if leverage and lending are allocated in a balanced manner between households and firms, then long term stable growth will be stimulated. This happens because lending is not decoupled from income generating productivity which allows the future repayment of consumptive debt. At the same time, if lending is mainly allocated to households and not used for productive investments, new income streams cannot be created, and household borrowers will not be able to repay the debt.

Our results suggest the dilemma faced by the financial system in making lending decisions in terms of the chasm between the interest of the single bank in the short term and the risk at systemic level in the long term. Lenders' decisions are mainly focused on the characteristic of the borrower: borrowers characterized by good collateral and a steady cash flow are preferred to those that have poorer collateral and more uncertain cash flow (Diamond, 1984; Lehmann and Neuberger, 2001). Historical evidence suggests that households tend to belong to the former group while firms tend to belong to the latter. When households buy a property on the one hand they have collateral that, in standard conditions, can be quite easily disposed by the 
bank if the borrower is delinquent and on the other hand households tend to count on a reliable and stable cash flow linked to their jobs. When firms buy assets, they have collateral characterized by quite a high level of specificity that cannot be so easily disposed to recover the loans if firms turn to be delinquent (Almeida and Campello, 2007; Williamson, 1988). In addition, the cash flows firms generate are less stable with respect the cash flow households can rely on (Cressy, 2006). Thus, as far as the banks are concerned, it makes sense to expand lending activities to households in order to reduce the risk incurred. However, when this behaviour is pursued at systemic level, firms will be constrained in accessing the finance they need to buy assets, expand production, and increase job opportunities (Kashyap and Stein, 2004; Martinelli, 1997; Piga and Atzeni, 2007): the economy will suffer. In other words, households' lending, by "crowding out" finance from firms, compromises a sustainable economic growth that has, in turn, an adverse effect on the very same leveraged households. Households will face a lower increase in salaries, higher probability to lose their job, lower opportunity to find a new job and eventually difficulties or incapability to repay the loans. The economic system faces a breaking point and historical evidence that suggests that households are low risk customers does not apply anymore. The consequence is that the very same banks that decided to pursue a low risk strategy in terms of lending (lend to households) are those that incur the higher risk (more exposed to households' delinquency). All in all, what can be a good strategy based on historical trends and proved to be good in the short term, turns to be a very dangerous one in the long term; what is a rational behaviour based on historical data at single lender level is an irrational behaviour at systemic level so that the sum of $n$ backward looking actors behaving rationally creates a consequence where all the actors are worse off. 
To the best of our knowledge, the potential systemic risk embedded in the risk minimization is not addressed in any way by the current bank regulation. If anything, current regulation (e.g. Basel II and Basel III) indirectly tends to increase the long-term systemic risk. In fact, current international and European banking regulations mainly stimulate banks to evaluate the risk of their customer (probability of default) and on being properly hedged against the potential loss (loss at default). Banks typically look at past data in order to estimate customer risk at both single customer level and at group level. Thus, in order to set up a portfolio that reduces the risk in terms of probability and loss at default, banks are implicitly stimulated to expand their lending activity to households that are historically lower risk, even at the expense of the firms, thus, increasing long term systemic risk. All in all, our evidence supports Caporale et al. (2015) who argue for policies to slow down household credit and encourage better allocation of credit to productive investments

\section{Concluding remarks}

The paper contributes to the extant literature by clarifying the role of financial intermediation in inducing the European financial crisis of 2008. By showing the links behind finance, capital formation and an economic growth decoupled from household income, we illustrate the detrimental effects of a lending expansion (Reinhart and Rogoff, 2009) towards households (Jordà et al., 2016; Mian and Sufi, 2014). More specifically for the European case, we show that not only excessive lending but excessive household leverage through mortgage lending too, exert a "crowding-out" effect on innovation and productive investments, ultimately resulting in a negative impact on sustainable growth. As such, we help clarify the mechanisms behind the decoupling of GDP growth to household income growth (Barba and Pivetti, 2009; 
Wisman, 2013), how financial intermediation can be detached from the real sector (Haiss et al., 2016), and the ways in which bank credit may exert a negative effect on long-run growth (Narayan and Narayan, 2013).

The evidence derived from this study stresses how financing choices grounded on past data and trends and that are perfectly rational in the short term and for an individual bank can structurally distort an economy and lead to unsustainable growth by not letting credit assume its economic function of stimulus to productive investments. We show that excessive finance is not a mere byproduct of an era characterized by limited productive investment and the divergence paths of household income to GDP, or that finance, as such, causes instability in a structurally sound system. Further, we show that excessive and rapid credit allocation towards households and mortgages, can have structural implications on the economy. Our empirical investigation suggests that sound capital allocation by the financial sector can promote a GDP growth and thus the growth of consumption/production of goods based on the growth of household income, by setting the underlining foundations based on productive capital formation. Moreover, we show that an economic system can enjoy the benefits of both household leverage and a growing housing sector only if it creates the necessary conditions to pay off the associated debt.

Our paper is subject to a number of caveats: despite our best efforts in econometric estimation, the well-known predicament of finance/growth endogeneity cannot be fully resolved. As such, while the strength of association in our variables is established conclusively, the causal effects remain the property of economic interpretation. The time-series of our sample is limited to the period 1995-2008. The time frame, while relevant to the crisis period, may not be long enough to capture divergence from a sustainable path; medium run cycles with higher capital accumulation may be present. 
Future research may be directed towards bank regulation concerned with the excessive allocation of credit to singular categories of borrowers. It is important to stress that in-place bank regulation focused on risk not only ignore the issue of productivity but also induce banks - acting rationally - to expand credit towards mortgages and away from productive, yet riskier, investments. As such, a mechanism that precludes the sum of short term risks reducing behaviour from generating long-term systemic risk is much sought.

Notwithstanding the limitations of the dataset and context, our study indicates that proper lending practices in terms of credit expansion and allocation of fin ancial resources between households and firms might play a more important role than has heretofore been acknowledged.

Acknowledgement: we would like to thank attendees of the "Finance and Economic Growth in the Aftermath of the Crisis" conference (Milan, 11-13 September 2017) for their helpful feedback. We also want to thank the editors Professor Bucci and Professor Russo as well as two anonymous reviewers. Their feedback allowed us to improve the analysis, develop it further and clarify some aspects of our research. 


\section{References}

Aliber, R., Kindleberger, C.P., 2015. Manias, Panics, and Crashes: A History of Financial Crises, 7th ed. Palgrave Macmillan.

Almeida, H., Campello, M., 2007. Financial Constraints, Asset tangibility, and Corporate Investment. Rev. Financ. Stud. 20, 1429-1460.

Arcand, J.L., Berkes, E., Panizza, U., 2015. Too much finance? J. Econ. Growth 20, 105-148.

Arellano, M., Bond., S., 1991. Some tests of specification for panel data: Monte Carlo evidence and an application to employment equations. Rev. Econom. Stud. 58, 277-297.

Arellano, M., Bover, O., 1995. Another look at the instrumental variable estimation of errorcomponents models. J. Econom. 68, 29-51.

Arestis, P., Baddeley, M., Sawyer, M., 2007. The relationship between capital stock, unemployment and wages in nine EMU countries. Bull. Econ. Res. 59, 125-148.

Arizala, F., Cavallo, E., Galindo, A., 2013. Financial Development and TFP Growth: Cross Country and Industrial-Level Evidence. Appl. Financ. Econ. 23, 433-448.

Baiardi, D., Morana, C., 2018. Financial development and income distribution inequality in the euro area. Econ. Model. 70, 40-55.

Baiardi, D., Morana, C., 2016. The Financial Kuznets Curve: Evidence for the euro area. J. Empir. Financ. 39, 265-269.

Baldwin, R., Giavazzi, F., 2015. The Eurozone Crisis a Consensus View of the Causes and a Few Possible Solutions. A VoxEU.org eBook.

Baltagi, B.H., 2008. Econometric Analysis of Panel Data. John Wiley and Sons, Chircester. Banerjee, B., Jesenko, M., 2015. Economic Growth and regional Disparities in Slovenia. Reg. Stud. $49,1722-1745$. 
Barba, A., Pivetti, M., 2009. Rising household debt: Its causes and macroeconomic implications - a long-period analysis. Cambridge J. Econ. 33, 113-137.

Barro, J.R., 1991. Economic Growth in a Cross Section of Countries. Q. J. Econ. 106, 407-443.

Beck, T., Büyükkarabacak, B., Rioja, F.K., Valev, N.T., 2012. Who gets the credit? And does it matter? Household vs. Firm Lending across Countries. BE J. Macroecon. 12, 1-42.

Beck, T., Demirgüc-Kunt, A., Maksimovic, V., 2008. Financing patterns around the world: Are small firms different? J. financ. econ. 89, 467-487.

Beck, T., Levine, R., Loayza, N., 2000. Finance and the Sources of Growth. J. financ. econ. 58, 261-300.

Benhabib, J., Spiegel, M.M., 2000. The Role of Financial Development in Growth and Investment. J. Econ. Growth 5, 341-360.

Blundell, R., Bond, S., 1998. Initial Conditions and Moment Restrictions in Dynamic Panel Data Models. J. Econom. 87, 115-143.

Brunnermeier, K.M., 2009. Deciphering the Liquidity and Credit Crunch 2007-2008. J. Econ. Perspect. 23, 77-100.

Büyükkarabacak, B., Krause, S., 2009. Studying the Effects of Household and Firm Credit on the Trade Balance: The Composition of Funds Matters. Econ. Inq. 47, 653-666.

Büyükkarabacak, B., Valev, N.T., 2010. The Role of Household and Business Credit in Banking Crises. J. Bank. Financ. 34, 1247-1256.

Calderón, C., Liu, L., 2003. The Direction of Causality between Financial Development and Economic Growth. J. Dev. Econ. 72, 321-334.

Caporale, M.G., Rault, G., Sova, D.A., Sova, R., 2015. Financial Development and Economic Growth: Evidence from 10 New European Union Members. Int. J. Financ. Econ. 20, 48-60. 
Caselli, F., Wilson, J.D., 2004. Importing Technology. J. Monet. Econ. 51, 1-32.

Cecchetti, S.G., Kharroubi, E., 2012. Reassessing the Impact of Finance on Growth, 2012.

Chouard, V., Fuentes Castro, D., Irac, D., 2014. Assessing the Losses in the Euro Area Potential Productivity Due to the Financial Crisis. Appl. Econ. 46, 2711-2720.

Coudert, V., Pouvelle, C., 2010. Assessing the Sustainability of Credit Growth: The Case of Central and Eastern European countries. Eur. J. Comp. Econ. 7, 87-120.

Cressy, R., 2006. Determinants of Small Firms Survival and Growth, in: Casson, M., Yeung, B., Basu, A., Wadeson, N. (Eds.), The Oxford Handbook of Entrepreneurship. Oxford University Press, Oxford, p. 161-193; 7.

De Long, J.B., Summers, L.H., 1991. Equipment Investment and Economic Growth. Q. J. Econ. $106,445-502$.

De Long, J.B., Summers, L.H., Abel, B.A., 1992. Equipment Investment and Economic Growth: How Strong Is the Nexus? Brookings Pap. Econ. Act. 2, 157-211.

Diamond, D.W., 1984. Financial Intermediation and Delegated Monitoring. Rev. Econ. Stud. 51, $393-414$.

Dias, D.A., Marques, C.R., Richmond, C., 2015. Misallocation and Productivity in the Lead Up to the Eurozone Crisis (No. International Finance Discussion Paper 1146).

Fitoussi, J.P., Saraceno, F., 2010. Europe: How Deep Is a Crisis? Policy Responses and Structural Factors behind Diverging Performances. J. Glob. Dev. 1, 1-19.

Flannery, M.J., Hankins, K.W., 2013. Estimating dynamic panel models in corporate finance. J. Corp. Financ. 19, 1-19.

Galindo, A., Schiantarelli, F., Weiss, A., 2007. Does Financial Liberalization Improve the Allocation of Investment? Micro-Evidence from Developing Countries. J. Dev. Econ. 83, 
$562-587$.

Georgantopoulos, G.A., Tsamis, D.A., Agoraki, M.-E.K., 2015. The Euro-Adoption Effect and the Bank, Market, and Growth Nexus: New Evidence from EU Panels. J. Econ. Asymmetries 12, 41-51.

Glick, R., Lansing, K.J., 2010. Global Household Leverage, House Prices, and Consumption. FRBSF Econ. Lett. 2010-01.

Glick, R., Lansing, K.J., 2009. U.S. Household Deleveraging and Future Consumption Growth. FRBSF Econ. Lett. 2009-16.

Hahn, J., Hausman, J., Kuersteiner, G., 2007. Long Difference Instrumental Variables Estimation for Dynamic Panel Models with Fixed Effects. J. Econom. 140, 574-617.

Haiss, P., Juvan, H., Mahlberg, B., 2016. The Impact of Financial Crises on the Finance-Growth Relationship: A European Perspective. Econ. Notes by Banca Monte dei Paschi di Siena SpA 2016, 1-22.

Han, J., Shen, Y., 2015. Financial Growth and Total Factor Productivity Growth: Evidence from China. Emerg. Mark. Financ. Trade 51, S261-S274.

Huang, R., Ritter, J.R., 2009. Testing Theories of Capital Structure and Estimating the Speed of Adjustment. J. Financ. Quant. Anal. 44, 237-271.

Jappelli, T., Pagano, M., 1994. Saving, Growth, and Liquidity Constraints. Q. J. Econ. 109, 83109.

Jappelli, T., Pagano, M., Bianco, M., 2005. Courts and Banks: Effects of Judicial Enforcement on Credit Markets. J. Money, Credit Bank. 37, 223-244.

Jordà, O., Schularick, O., Taylor, M.A., 2016. The Great Mortgaging: Housing Finance, Crises and Business Cycles. Econ. Policy 31, 107-152. 
Kaminsky, L.G., Reinhart, M.C., 1999. The Twin Crises: The Causes of Banking and Balanceof-Payments Problems. Am. Econ. Rev. 89, 473-500.

Kashyap, A.K., Stein, J.C., 2004. Cyclical implications of the Basel II capital standards. Econ. Perspect. - Fed. Reserv. Banks Chicago, 1Q, 18-31.

Kim, J., Park, J., 2018. The Role of Total Factor Productivity Growth in Middle-Income Countries. Emerg. Mark. Financ. Trade 54, 1264-1284.

King, R., Lavine, R., 1993. Finance and growth: Schumpeter might be right. Q. J. Econ. 108, $717-738$.

Kose, M.A., Prasad, E.S., Taylor, A.D., 2011. Thresholds in the process of international financial integration. J. Int. Money Financ. 30, 147-179.

La Porta, R., Lopez-de-Silvanes, F., Shleifer, A., Vishny, R.W., 1998. Law and Finance. J. Polit. Econ. 106, 1113-1155.

La Porta, R., Lopez-de-Silvanes, F., Shleifer, A., Vishny, R.W., 1997. Legal Determinants of External Finance. J. Finance 52, 1131-1150.

Leblebicioğlu, A., Madariaga, J., 2015. Financial Flows, Composition of Capital, and Growth. IMF Econ. Rev. 63, 325-352.

Lehmann, E., Neuberger, D., 2001. Do lending relationships matter? Evidence from bank survey data in Germany. J. Econ. Behav. Organ. 45, 339-359.

Levine, R., 2005. Finance and Growth: Theory and Evidence, in: Aghion, P., Durlauf, N. (Eds.), Handbook of Economic Growth. Elsevir, Amsterdam, pp. 865-934.

Levine, R., 1999. Law, Finance, and Economic Growth. J. Financ. Intermediation 8, 8-35.

Martinelli, C., 1997. Small firms, borrowing constraints, and reputation,. J. Econ. Behav. Organ. $33,91-105$. 
Mian, A., Sufi, A., 2014. House of Debt. How They (and You) Caused the Great Recession, and How We Can Prevent It from Happening Again. The University of Chicago Press., Chicago, IL.

Mian, A., Sufi, A., 2009. The Consequences of Mortgage Credit Expansion: Evidence from the US Mortgage Default Crisis. 1449-1496. Q. J. Econ. 124, 1449-1496.

Mian, A.R., Rao, K., Sufi, A., 2013. Household Balance Sheets, Consumption, and the Economic Slump, Research Paper. Chicago, IL.

Moro, A., Maresch, D., Ferrando, A., 2016. Creditor Protection, Judicial Enforcement and Credit Access. Eur. J. Financ. 24, 250-281.

Narayan, K.P., Narayan, S., 2013. The Short-Run Relationship between the Financial System and Economic Growth: New Evidence from Regional Panels. Int. Rev. Financ. Anal. 29, $70-78$.

OECD, 2009. Why Has Productivity Growth Declined.

Ollivaud, P., Turner, D., 2015. The Effect of teh Global Financial Crisis on OECD Potential Output, OECD Journal: Economic Studies.

Piga, C.A., Atzeni, G., 2007. R\&D Investment, Credit Rationing and Sample Selection. Bull. Econ. Res. 59, 149-178.

Rajan, R., Zingales, L., 1998. Financial dependence and growth. Am. Econ. Rev. 88, 559-586.

Reinhart, C.M., Rogoff, K., 2009. This Time Is Different: Eight Centuries of Financial Folly. Princeton University Press., Princeton NJ.

Rousseau, P.L., Wachtel, P., 2011. What Is Happening to the Impact of Financial Deepening on Economic Growth? Econ. Inq. 49, 276-288.

Sandliers, G., Wright, M.L.J., 2014. The Cost of Financial Crisis: Resource Misallocation, 
Productivity, and Welfare in the 2001 Argentine Crisis. Scand. J. Econ. 116, 87-127.

Schumpeter, J.A., 1934. The Theory of Economic Development: An Inquiry into Profits, Capital, Credit, Interest, and the Business Cycle. Routledge, New Jersey.

Stiglitz, J.E., Sen, A., Fitoussi, J.P., 2009. Commission on the Measurement of Economic Performance and Social Progress.

Summers, L.H., 2014. US Economic Prospects: Secular Stagnation, Hysteresis, and the Zero Lower Bound. Bus. Econ. 49, 65-73.

Tridico, P., 2012. Financial Crisis and Global Imbalances: Its Labour Market Origins and the Aftermath. Cambridge J. Econ. 36, 17-42.

Turner, A., 2015. Between Debt and the Devil: Money, Credit, and Fixing Global Finance. Princeton University Press, Princeton NJ.

Williamson, O.E., 1988. Corporate Finance and Corporate Governance. J. Finance 43, 567-591. Wisman, J.D., 2013. Wage Stagnation, Rising Inequality and the Financial Crisis of 2008. Cambridge J. Econ. 37, 921-945.

Wurgler, J., 2000. Financial Markets and the Allocation of Capital. J. financ. econ. 58, 187-214. 
Table 1: Divergence between Income Growth and GDP growth Per Country

\begin{tabular}{|c|c|c|c|c|c|}
\hline Country & BaseYear & $\begin{array}{c}\text { Pre-Recession } \\
\text { Year }\end{array}$ & $\mathrm{g}^{\mathrm{INCOME}}$ & $\mathrm{g}^{\mathrm{GDP}}$ & $\begin{array}{l}\text { Divergence } \\
\text { of Growth }\end{array}$ \\
\hline Austria & 1996 & 2007 & $17.5 \%$ & $22.3 \%$ & $27.6 \%$ \\
\hline Belgium & 1996 & 2007 & $12.0 \%$ & $24.4 \%$ & $103.0 \%$ \\
\hline Bulgaria & 2002 & 2008 & $33.8 \%$ & $47.0 \%$ & $39.2 \%$ \\
\hline Croatia & 2002 & 2008 & $22.2 \%$ & $35.9 \%$ & $62.0 \%$ \\
\hline Cyprus & 1996 & 2008 & $40.9 \%$ & $41.8 \%$ & $2.2 \%$ \\
\hline CzechRep. & 1996 & 2007 & $30.5 \%$ & $43.8 \%$ & $43.7 \%$ \\
\hline Denmark & 1996 & 2007 & $9.2 \%$ & $24.5 \%$ & $166.8 \%$ \\
\hline Estonia & 1996 & 2007 & $135.3 \%$ & $177.4 \%$ & $31.1 \%$ \\
\hline Finland & 1996 & 2008 & $43.2 \%$ & $49.3 \%$ & $14.0 \%$ \\
\hline France & 1996 & 2007 & $18.8 \%$ & $20.4 \%$ & $8.4 \%$ \\
\hline Germany & 1996 & 2007 & $4.8 \%$ & $9.6 \%$ & $99.3 \%$ \\
\hline Hungary & 1996 & 2007 & $34.2 \%$ & $50.4 \%$ & $47.7 \%$ \\
\hline Ireland & 2002 & 2008 & $17.9 \%$ & $13.6 \%$ & $-24.0 \%$ \\
\hline Italy & 1996 & 2007 & $8.7 \%$ & $17.9 \%$ & $106.4 \%$ \\
\hline Latvia & 1996 & 2008 & $198.7 \%$ & $211.7 \%$ & $6.5 \%$ \\
\hline Lithuania & 1996 & 2008 & $158.7 \%$ & $145.5 \%$ & $-8.30 \%$ \\
\hline Luxembourg & 2006 & 2008 & $4.3 \%$ & $6.1 \%$ & $40.4 \%$ \\
\hline Netherlands & 1996 & 2007 & $14.5 \%$ & $33.8 \%$ & $133.3 \%$ \\
\hline Poland & 1996 & 2008 & $41.8 \%$ & $62.7 \%$ & $49.8 \%$ \\
\hline Portugal & 1996 & 2008 & $24.2 \%$ & $28.2 \%$ & $16.5 \%$ \\
\hline Romania & 1998 & 2008 & $135.7 \%$ & $155.2 \%$ & $14.3 \%$ \\
\hline Slovakia & 1996 & 2008 & $46.7 \%$ & $50.8 \%$ & $8.7 \%$ \\
\hline Slovenia & 1996 & 2008 & $39.5 \%$ & $55.3 \%$ & $39.9 \%$ \\
\hline Spain & 2000 & 2008 & $13.5 \%$ & $20.0 \%$ & $48.3 \%$ \\
\hline Sweden & 1996 & 2008 & $30.5 \%$ & $36.5 \%$ & $19.6 \%$ \\
\hline$U . K$ & 1996 & 2008 & $29.7 \%$ & $43.6 \%$ & $46.8 \%$ \\
\hline
\end{tabular}

Notes:This table presents country-wide statistics regarding the divergence of household income growth to GDP growth. Base Year represents the first year of growth measurement. Pre-recession year represents the last year before a specific country enters the financial crisis. g $^{\mathrm{INCOME}}$ represents household income growth for the period between the base year and the pre-recession year. $\mathrm{g}^{\mathrm{GDP}}$ represents GDP growth for the period between the base year and the pre-recession year. Divergence of growth equals $\left(\mathrm{g}^{\mathrm{GDP}} / \mathrm{g}^{\mathrm{INCOME}}\right)-1$. 
Table 2: Descriptive Statistics

\begin{tabular}{|c|c|c|c|c|c|c|c|c|}
\hline & $N$ & Mean & $\begin{array}{l}\text { Std } \\
D V\end{array}$ & 5th Pctl & $\begin{array}{l}25 \text { th } \\
\text { Pctl }\end{array}$ & $\begin{array}{l}\text { Media } \\
n\end{array}$ & $\begin{array}{l}75 \text { th } \\
\text { Pctl }\end{array}$ & $\begin{array}{l}\text { 95th } \\
\text { Pctl }\end{array}$ \\
\hline$I N C 2 G D P(\%)$ & 272 & -0.747 & 2.241 & -3.800 & -1.900 & -0.700 & 0.250 & 2.700 \\
\hline HOUSECAP (\%) & 293 & 2.904 & 12.850 & -12.800 & -2.800 & 1.500 & 5.800 & 25.000 \\
\hline CORPDEBT (\%) & 289 & 4.377 & 9.306 & -6.850 & -1.084 & 3.808 & 8.594 & 17.867 \\
\hline HHLEVERAGE (\%) & 272 & 11.65 & 16.459 & -6.092 & 3.305 & 7.114 & 16.000 & 47.446 \\
\hline NCREDIT (\%) & 264 & 13.25 & 53.582 & -73.186 & -11.519 & 13.584 & 38.913 & 105.20 \\
\hline FIXASSETS (\%) & 293 & -0.453 & 5.586 & -9.200 & -2.300 & -0.500 & 1.200 & 7.000 \\
\hline TFXCFORM (\%) & 293 & 2.23 & 2.99 & -1.73 & 0.22 & 1.42 & 4.24 & 6.41 \\
\hline GDPPC (\%) & 305 & 4.050 & 3.920 & 2.927 & 3.243 & 3.938 & 4.155 & 5.982 \\
\hline
\end{tabular}

Notes: This table presents detail statistics for all country-year observations for the period prior to the financial crisis.INC2GDP equals growth in household net disposable income divided by GDP. HOUSECAP is a proxy of housing fixed capital formation calculated as growth in residential construction divided by total gross fixed capital formation. CORPDEBT is a proxy for growth in firms' debt estimated as the growth in firms' debt to GDP. HHLEVERAGE is a proxy for growth in household leverage calculated as growth in household loans to household gross disposable income. NCREDIT represents growth in annual credit flows for non-financial firms, non-profit institutions and households. FIXEDASSETS is growth in fixed capital formation of productive assets by the sum of buildings other than residential construction (i.e. commercial and industry), machines and equipment related to information and communication technology, intellectual property products, cultivated biological resources and other machines \& equipment divided by total gross fixed capital formation. TFXCFORM is total fixed formation. GDPPC is real gross domestic product per capita growth. 
Table 3: Difference-GMM regressions

\begin{tabular}{|c|c|c|c|c|c|c|}
\hline & (I) & (II) & (III) & $(I V)$ & $(V)$ & $(V I)$ \\
\hline L1_INC2GDP & $\begin{array}{c}0.048 \\
(0.066)\end{array}$ & $\begin{array}{c}0.048 \\
(0.091)\end{array}$ & $\begin{array}{c}0.059 \\
(0.095)\end{array}$ & $\begin{array}{c}0.032 \\
(0.097)\end{array}$ & $\begin{array}{c}0.026 \\
(0.098)\end{array}$ & $\begin{array}{l}-0.001 \\
(0.098)\end{array}$ \\
\hline HHLEVERAGE & $\begin{array}{c}-0.118^{* * *} \\
(0.002)\end{array}$ & $\begin{array}{c}-0.111^{* * *} \\
(0.003)\end{array}$ & $\begin{array}{c}-0.115^{* * *} \\
(0.003)\end{array}$ & $\begin{array}{c}-0.123^{* * *} \\
(0.002)\end{array}$ & $\begin{array}{c}-0.104 * * * \\
(0.003)\end{array}$ & $\begin{array}{c}-0.089 * * * \\
(0.003)\end{array}$ \\
\hline CORPDEBT & $\begin{array}{l}0.061^{*} \\
(0.049)\end{array}$ & $\begin{array}{c}0.025 \\
(0.047)\end{array}$ & $\begin{array}{l}0.059^{*} \\
(0.056)\end{array}$ & $\begin{array}{l}0.082^{*} \\
(0.062)\end{array}$ & $\begin{array}{l}0.022^{*} \\
(0.017)\end{array}$ & $\begin{array}{l}0.029^{*} \\
(0.018)\end{array}$ \\
\hline NCREDIT & $\begin{array}{c}-0.012 * * * \\
(0.008)\end{array}$ & $\begin{array}{c}-0.007 * * * \\
(0.001)\end{array}$ & $\begin{array}{c}-0.005^{* * *} \\
(0.001)\end{array}$ & $\begin{array}{c}-0.007 * * * \\
(0.001)\end{array}$ & $\begin{array}{c}-0.008^{* * *} \\
(0.001)\end{array}$ & $\begin{array}{c}-0.007 * * * \\
(0.001)\end{array}$ \\
\hline INFLATION & & $\begin{array}{c}0.187 \\
(0.503)\end{array}$ & $\begin{array}{c}0.213^{* *} \\
(0.083)\end{array}$ & $\begin{array}{l}0.171^{*} \\
(0.072)\end{array}$ & $\begin{array}{c}0.176 \\
(0.179)\end{array}$ & $\begin{array}{c}0.267 \\
(0.782)\end{array}$ \\
\hline$T R A D E$ & & & $\begin{array}{c}-0.513 \\
(4.309)\end{array}$ & $\begin{array}{c}-0.901 * \\
(0.520)\end{array}$ & $\begin{array}{l}-0.494 \\
(0.618)\end{array}$ & $\begin{array}{c}0.540 \\
(0.593)\end{array}$ \\
\hline HUMANCAPITAL & & & & $\begin{array}{c}3.299 * * \\
(0.104)\end{array}$ & $\begin{array}{c}2.851 * * \\
(1.237)\end{array}$ & $\begin{array}{c}7.675 \\
(14.910)\end{array}$ \\
\hline GOVERMENT & & & & & $\begin{array}{l}10.521 \\
(9.162)\end{array}$ & $\begin{array}{l}9.103 * * \\
(0.1304)\end{array}$ \\
\hline$L A B O U R$ & & & & & & $\begin{array}{c}0.140 \\
(0.151)\end{array}$ \\
\hline $\begin{array}{l}\text { N. of Instruments } \\
\text { AR(I) z } \\
(p-\text { val })\end{array}$ & $\begin{array}{c}44 \\
-2.58 * * * \\
(0.009)\end{array}$ & $\begin{array}{c}44 \\
-2.60 * * * \\
(0.009)\end{array}$ & $\begin{array}{c}44 \\
-2.55^{* *} \\
(0.01)\end{array}$ & $\begin{array}{c}44 \\
-2.31 * * \\
(0.021)\end{array}$ & $\begin{array}{c}44 \\
-2.42^{* *} \\
(0.015)\end{array}$ & $\begin{array}{c}44 \\
-2.33 * * \\
(0.019)\end{array}$ \\
\hline $\begin{array}{l}A R(I I) z \\
(p-v a l)\end{array}$ & $\begin{array}{c}-1.13 \\
(0.258)\end{array}$ & $\begin{array}{c}-1.01 \\
(0.312)\end{array}$ & $\begin{array}{c}-0.93 \\
(0.352)\end{array}$ & $\begin{array}{c}-0.65 \\
(0.515)\end{array}$ & $\begin{array}{c}-0.42 \\
(0.674)\end{array}$ & $\begin{array}{c}0.14 \\
(0.889)\end{array}$ \\
\hline $\begin{array}{l}\text { Hansen chi }{ }^{2} \\
(p \text {-val) }\end{array}$ & $\begin{array}{c}22.17 \\
(0.178)\end{array}$ & $\begin{array}{c}18.50 \\
(0.295)\end{array}$ & $\begin{array}{c}22.03 \\
(0.133)\end{array}$ & $\begin{array}{c}22.27 \\
(0.121)\end{array}$ & $\begin{array}{c}19.23 \\
(0.156)\end{array}$ & $\begin{array}{c}17.79 \\
(0.165)\end{array}$ \\
\hline
\end{tabular}

Notes: This table gives regression results for models I-V with INC2GDP the dependent variable. INC2GDP equals growth in real household net disposable income per capita divided by real GDP per capita. INFLATION is natural log of $1+$ country/year inflation rate. TRADE is a proxy of trade openness and equals the natural $\log$ of exports plus imports, the sum scaled by GDP. HUMANCAPITAL is a proxy of human capital and is calculated as the natural log of average years of schooling. GOVERNMENT is the natural log of total government expenditure scaled by GDP. $\angle A B O R$ is the growth (log difference) in labor force defined as the sum of employed and unemployed persons. CORPDEBT is a proxy for growth (log difference) in firms' debt estimated as the growth in firms' debt to GDP. HHLEVERAGE is a proxy for growth (log difference) in household leverage calculated as growth in household loans to household gross disposable income. NCREDIT represents growth (log difference) in annual credit flows for nonfinancial firms, non-profit institutions and households. Refer to section III for a detailed description of the variables. Coefficients correspond to Difference-GMM regressions with lagged-transformed explanatory variables as valid instruments ( Arellano and Bond, 1991). Lagged variables are transformed by the method of orthogonal deviations (Arellano and Bover, 1995. Figures in brackets correspond to Windmeijer (2005) robust errors. The superscripts ***, $* *, *$ denote significance at the $1 \%, 5 \%$, and $10 \%$ level, respectively. $A R(I), A R(I I)$ are tests of serial correlation of order 1 and 2 using residuals of first differences, asymptotically distributed as $N(0,1)$, under the null of no serial 
correlation. The Hansen statistic corresponds to a test of over-identifying restrictions, asymptotically distributed as $x^{2}$ under the null hypothesis of that the joint exogeneity of the instruments is satisfied.

Table 4: Alternative Dynamic Panel Estimators and External Instrument

\begin{tabular}{|c|c|c|c|c|c|c|}
\hline & \multicolumn{2}{|c|}{ Panel A: Diff-GMM } & \multicolumn{2}{|c|}{ Panel B:SGMM } & \multicolumn{2}{|c|}{$\begin{array}{l}\text { Panel C: LD4 } \\
\text { Estimator }\end{array}$} \\
\hline & (I) & (II) & (I) & (II) & (I) & (II) \\
\hline L1_INC2GDP & $\begin{array}{l}-0.001 \\
(0.098)\end{array}$ & $\begin{array}{l}-0.054 \\
(0.084)\end{array}$ & $\begin{array}{c}0.013 \\
(0.097)\end{array}$ & $\begin{array}{c}0.004 \\
(0.098)\end{array}$ & $\begin{array}{l}-0.087 \\
(0.247)\end{array}$ & $\begin{array}{l}-0.001 \\
(0.361)\end{array}$ \\
\hline HHLEVERAGE & $\begin{array}{c}-0.089 * * * \\
(0.003)\end{array}$ & $\begin{array}{c}-0.081 * * * \\
(0.003)\end{array}$ & $\begin{array}{c}-0.096 * * * \\
(0.023)\end{array}$ & $\begin{array}{c}-0.091 * * * \\
(0.019)\end{array}$ & $\begin{array}{c}-0.057 * * \\
(0.029)\end{array}$ & $\begin{array}{c}-0.094 * * * \\
(<0.001)\end{array}$ \\
\hline CORPDEBT & $\begin{array}{l}0.029^{*} \\
(0.018)\end{array}$ & $\begin{array}{l}0.034^{*} \\
(0.024)\end{array}$ & $\begin{array}{c}0.054 * * \\
(0.024)\end{array}$ & $\begin{array}{c}0.071 * * \\
(0.030)\end{array}$ & $\begin{array}{c}0.082 * * \\
(0.037)\end{array}$ & $\begin{array}{c}0.059 * * \\
(0.024)\end{array}$ \\
\hline NCREDIT & $\begin{array}{c}-0.007 * * * \\
(0.001)\end{array}$ & $\begin{array}{c}-0.009 * * \\
(0.004)\end{array}$ & $\begin{array}{c}-0.007 * * \\
(0.003)\end{array}$ & $\begin{array}{c}-0.008 * * * \\
(0.003)\end{array}$ & $\begin{array}{c}-0.007 * * \\
(0.003)\end{array}$ & $\begin{array}{c}-0.005 * * * \\
(<0.001)\end{array}$ \\
\hline INFLATION & $\begin{array}{c}0.267 \\
(0.782)\end{array}$ & $\begin{array}{c}0.714 \\
(1.198)\end{array}$ & $\begin{array}{c}0.801 \\
(0.503)\end{array}$ & $\begin{array}{c}0.181 \\
(0.525)\end{array}$ & $\begin{array}{c}0.133 \\
(0.194)\end{array}$ & $\begin{array}{c}0.484 \\
(0.527)\end{array}$ \\
\hline TRADE & $\begin{array}{c}0.540 \\
(0.593)\end{array}$ & $\begin{array}{c}0.580 \\
(0.459)\end{array}$ & $\begin{array}{c}0.503 \\
(1.270)\end{array}$ & $\begin{array}{c}0.854 \\
(1.004)\end{array}$ & $\begin{array}{c}0.763 * * \\
(0.256)\end{array}$ & $\begin{array}{l}-1.946 \\
(2.672)\end{array}$ \\
\hline HUMANCAPITAL & $\begin{array}{c}7.675 \\
(14.910)\end{array}$ & $\begin{array}{l}2.214^{*} \\
(0.995)\end{array}$ & $\begin{array}{c}3.425 \\
(2.330)\end{array}$ & $\begin{array}{l}1.860 \\
(2.779)\end{array}$ & $\begin{array}{c}3.726 \\
(5.810)\end{array}$ & $\begin{array}{c}8.147 \\
(7.863)\end{array}$ \\
\hline GOVERMENT & $\begin{array}{l}9.103 * * \\
(0.1304)\end{array}$ & $\begin{array}{c}5.618 \\
(7.795)\end{array}$ & $\begin{array}{l}3.852 * * \\
(1.974)\end{array}$ & $\begin{array}{c}2.883 \\
(2.215)\end{array}$ & $\begin{array}{c}7.631 \\
(4.778)\end{array}$ & $\begin{array}{l}4.156 \\
(4.657)\end{array}$ \\
\hline$L A B O U R$ & $\begin{array}{c}0.140 \\
(0.151)\end{array}$ & $\begin{array}{c}0.145 \\
(0.138)\end{array}$ & $\begin{array}{c}0.126 \\
(0.791)\end{array}$ & $\begin{array}{c}0.143 \\
(0.136)\end{array}$ & $\begin{array}{c}0.008 \\
(0.013)\end{array}$ & $\begin{array}{c}0.058 \\
(0.122)\end{array}$ \\
\hline $\begin{array}{l}\text { N. of Instruments } \\
A R(I) z\end{array}$ & $\begin{array}{c}44 \\
-2.33 * * \\
(0.019)\end{array}$ & $\begin{array}{c}60 \\
-2.82 * * * \\
(0.004)\end{array}$ & $\begin{array}{c}89 \\
-2.39 * * \\
(0.016)\end{array}$ & $\begin{array}{c}124 \\
-3.03 * * * \\
(0.002)\end{array}$ & n. $\operatorname{diff}=4$ & n. $\operatorname{diff}=4$ \\
\hline$A R(I I) z$ & $\begin{array}{c}0.14 \\
(0.889)\end{array}$ & $\begin{array}{c}-0.37 \\
(0.711)\end{array}$ & $\begin{array}{c}0.22 \\
(0.825)\end{array}$ & $\begin{array}{c}-0.60 \\
(0.548)\end{array}$ & n.iter $=3$ & n.iter $=3$ \\
\hline Hansen chi ${ }^{2}$ & $\begin{array}{l}17.79 \\
(0.165)\end{array}$ & $\begin{array}{l}17.95 \\
(0.206)\end{array}$ & $\begin{array}{c}19.07 \\
(0.641)\end{array}$ & $\begin{array}{c}19.87 \\
(0.704)\end{array}$ & 18.52 & 21.31 \\
\hline
\end{tabular}

Notes: The table gives results from alternative dynamic panel estimation methods by means of robustness. Panel $A$ corresponds to first-differencing GMM (Arellano and Bond, 1991) where lagged variables are transformed by the method of orthogonal deviations (Arellano and Bover, 1995). Panel B corresponds to System-GMM with laggedtransformed explanatory variables as valid instruments (Blundell and Bond, 1998). Lagged variables are transformed by the method of orthogonal deviations (Arellano and Bover, 1995). Panel C corresponds to the Long Differencing Estimator (Hahn et al.'s, 2007) using 4 periods for differencing (Huang and Ritter, 2009) and 3 iterations. Model (I) in all panels uses lagged-transformed explanatory variables as valid instruments. Model (II) in all panels adds legal origin as an external instrument (Beck et al, 2000). All variables are as defined in table 3. The superscripts $* * *, * * *$ denote significance at the $1 \%, 5 \%$, and $10 \%$ level, respectively. $A R(I), A R(I I)$, where reported, are tests of serial correlation of order 1 and 2 using residuals of first differences, asymptotically distributed 
as $N(0,1)$, under the null of no serial correlation. The Hansen statistic corresponds to a test of over-identifying restrictions, asymptotically distributed as $x^{2}$ under the null hypothesis of that the joint exogeneity of the instruments is satisfied. 
Table 5: Split Regressions

\begin{tabular}{|c|c|c|c|c|c|c|c|c|c|}
\hline \multicolumn{10}{|c|}{ PANEL A: Split Regressions based on GDP growth } \\
\hline & L1_INC2GDP & HHLEVG & CORPDEBT & NCREDIT & INFLATION & TRADE & HCAPITAL & GOVERNT & LABOUR \\
\hline High & $\begin{array}{l}-0.013 \\
(0.082)\end{array}$ & $\begin{array}{c}-0.110^{* * *} \\
(0.003)\end{array}$ & $\begin{array}{c}0.025 \\
(0.068)\end{array}$ & $\begin{array}{c}-0.144 \\
(0.505)\end{array}$ & $\begin{array}{l}-0.687 \\
(0.892)\end{array}$ & $\begin{array}{l}-0.087 \\
(0.517)\end{array}$ & $\begin{array}{l}2.625^{*} \\
(1.464)\end{array}$ & $\begin{array}{c}8.962 \\
(8.281)\end{array}$ & $\begin{array}{l}0.174^{*} \\
(0.143)\end{array}$ \\
\hline Low & $\begin{array}{c}0.016 \\
(0.136)\end{array}$ & $\begin{array}{c}-0.202 * * \\
(0.082)\end{array}$ & $\begin{array}{l}0.020^{*} \\
(0.013)\end{array}$ & $\begin{array}{c}-0.194 \\
(0.847)\end{array}$ & $\begin{array}{c}0.703 \\
(1.639)\end{array}$ & $\begin{array}{c}9.608 \\
(6.214)\end{array}$ & $\begin{array}{l}-1.974 \\
(1.271)\end{array}$ & $\begin{array}{c}2.157 \\
(1.518)\end{array}$ & $\begin{array}{c}4.279 \\
(4.631)\end{array}$ \\
\hline \multicolumn{10}{|c|}{ PANEL B: Split Regressions based Initial Level of Household Leverage } \\
\hline & L1_INC2GDP & HHLEVG & CORPDEBT & NCREDIT & INFLATION & TRADE & HCAPITAL & GOVERNT & LABOUR \\
\hline High & $\begin{array}{c}0.022 \\
(0.093)\end{array}$ & $\begin{array}{c}-0.200 * * * \\
(0.094)\end{array}$ & $\begin{array}{c}0.136^{* *} \\
(0.058)\end{array}$ & $\begin{array}{c}-0.152 \\
(0.565)\end{array}$ & $\begin{array}{c}0.177 \\
(0.848)\end{array}$ & $\begin{array}{c}1.356 \\
(1.064)\end{array}$ & $\begin{array}{c}0.789 \\
(2.677)\end{array}$ & $\begin{array}{c}14.441 \\
(14.567)\end{array}$ & $\begin{array}{l}-3.306 \\
(4.772)\end{array}$ \\
\hline Low & $\begin{array}{l}-0.019 \\
(0.045)\end{array}$ & $\begin{array}{c}-0.112 * * * \\
(0.024)\end{array}$ & $\begin{array}{c}0.045 \\
(0.036)\end{array}$ & $\begin{array}{l}-0.058 \\
(0.083)\end{array}$ & $\begin{array}{l}-0.147 \\
(0.105)\end{array}$ & $\begin{array}{c}0.579 \\
(0.438)\end{array}$ & $\begin{array}{l}13.475 \\
(7.993)\end{array}$ & $\begin{array}{l}11.550 \\
(7.993)\end{array}$ & $\begin{array}{c}0.166 \\
(0.171)\end{array}$ \\
\hline \multicolumn{10}{|c|}{ PANEL C: Split Regressions based on 1999 EUROZONE Membership } \\
\hline & $L 1 \_I N C 2 G D P$ & $H H L E V G$ & CORPDEBT & NCREDIT & INFLATION & TRADE & HCAPITAL & GOVERNT & LABOUR \\
\hline$Y E S$ & $\begin{array}{c}0.012 \\
(0.076)\end{array}$ & $\begin{array}{c}-0.160 * * * \\
(0.081)\end{array}$ & $\begin{array}{c}0.059 * * \\
(0.018)\end{array}$ & $\begin{array}{c}-0.159 \\
(0.458)\end{array}$ & $\begin{array}{c}0.216 \\
(0.121)\end{array}$ & $\begin{array}{c}1.143 \\
(6.229)\end{array}$ & $\begin{array}{c}2.698 \\
(2.443)\end{array}$ & $\begin{array}{c}28.239^{* *} \\
(11.884)\end{array}$ & $\begin{array}{l}-25.651 \\
(41.845)\end{array}$ \\
\hline$N O$ & $\begin{array}{c}-0.014 \\
(0.064)\end{array}$ & $\begin{array}{c}-0.110 * * * \\
(0.002)\end{array}$ & $\begin{array}{c}0.025 \\
(0.066)\end{array}$ & $\begin{array}{l}-0.726 \\
(0.627)\end{array}$ & $\begin{array}{l}-0.174 \\
(0.850)\end{array}$ & $\begin{array}{c}2.378 \\
(3.659)\end{array}$ & $\begin{array}{l}2.953^{*} \\
(1.432)\end{array}$ & $\begin{array}{l}12.017 \\
(8.731)\end{array}$ & $\begin{array}{c}0.147 \\
(0.154)\end{array}$ \\
\hline
\end{tabular}

Notes: This table gives split regression results for equation 1 with $I N C 2 G D P$ the dependent variable. Panel A presents split regression results for the high and low GDP growth portfolios. Panel B presents split regression results on the basis of 1999 country membership in the Eurozone, or not. Panel C presents split regression results for the high/low initial level of household leverage. INC2GDP equals growth in household net disposable income pc divided by GDP pc. INFLATION is natural log of $1+$ country/year inflation rate. TRADE is a proxy of trade openness and equals the natural log of exports plus imports, the sum scaled by GDP. HUMANCAPITAL is a proxy of human capital and is calculated as the natural log of average years of schooling. GOVERNMENT is the natural log of total government expenditure scaled by GDP. $\angle A B O R$ is the growth (log diff.) in labor force defined as the sum of employed and unemployed persons. CORPDEBT is a proxy for growth (log diff.) in firms' debt estimated as the growth in firms' debt to GDP. HHLEVERAGE is a proxy for growth (log diff.) in household leverage calculated as growth in household loans to household gross disposable income. NCREDIT represents growth (log diff.) in annual credit flows for non-financial firms, non-profit institutions and households. Coefficients correspond to Difference-GMM regressions with lagged-transformed explanatory variables as valid instruments ( Arellano and Bond, 1991). Lagged variables are transformed by the method of orthogonal deviations (Arellano and Bover, 1995. Figures in brackets correspond to Windmeijer (2005) robust errors. The superscripts $* * *, * *$, and $*$ denote significance at the $1 \%, 5 \%$, and $10 \%$ level, respectively. Unreported $A R$ (II) tests reject the null of serial residual correlation once residuals are differences, while (unreported) Hansen tests reject the null of over identification. 
Table 6: 2SLS regressions: Relation between INC2GDP and composition of capital

(I)

(II)

(III)

\begin{tabular}{lccc}
\hline \multirow{2}{*}{ INFLATION } & 0.374 & 0.302 & 0.528 \\
TRADE & $(0.632)$ & $(0.713)$ & $(0.513)$ \\
& -0.421 & $-3.087^{*}$ & $-3.265^{*}$ \\
HUMANCAPITAL & $(0.925)$ & $(0.077)$ & $(0.052)$ \\
GOVERMENT & 9.047 & $12.21^{* *}$ & $12.51^{* *}$ \\
& $(0.430)$ & $(0.028)$ & $(0.019)$ \\
LABOR & 5.028 & -0.210 & -2.505 \\
HOUSECAP & $(0.484)$ & $(0.946)$ & $(0.465)$ \\
& -0.136 & -0.186 & -0.233 \\
FIXASSETS & $(0.863)$ & $(0.850)$ & $(0.805)$ \\
& $-0.388^{* * *}$ & & -0.216 \\
Indirect Effect of & $(0.003)$ & & $0.179)$ \\
HHLEVERAGE & & $1.177^{* * *}$ & $0.881 * *$ \\
& & $(0.005)$ & $(0.050)$ \\
Wald chi ${ }^{2}$ & $-0.095^{* * *}$ & $-0.035^{* * *}$ & \\
Prob $>$ chi & & $(<0.001)$ & \\
NotE: & $(<0.001)$ & 8.21 & $(0.059)$ \\
\hline
\end{tabular}

Notes: This table gives regression results for models I-III with INC2GDP the dependent variable. INC2GDP equals growth in real household net disposable income per capita divided by real GDP per capita. INFLATION is natural log of $1+$ country/year inflation rate. TRADE is a proxy of trade openness and equals the natural log of exports plus imports, the sum scaled by GDP. HUMANCAPITAL is a proxy of human capital and is calculated as the natural log of average years of schooling. GOVERNMENT is the natural log of total government expenditure scaled by GDP. $\angle A B O R$ is the growth (log difference) in labor force defined as the sum of employed and unemployed persons. HOUSECAP is a proxy of housing fixed capital formation calculated as growth (log difference) in residential construction divided by gross fixed capital formation. FIXASSETS is the growth (log difference) of the sum of buildings other than residential construction (i.e. commercial and industry), machines and equipment related to information and communication technology, intellectual property products, cultivated biological resources and other machines \&equipment. Refer to section III for a detailed description of the variables. Regressions coefficients correspond to FE-2SLS estimators as in Semykina and Wooldridge (2010). We estimate the system of equations 3a, $3 \mathrm{~b}$ (column I), $4 \mathrm{a}, \mathrm{b}$ (Column II) and the system of equations 5 (column II).Indirect effect of HHLEVERAGE equals $\hat{\beta}_{1} x \hat{\alpha}_{1}$ for model $(I)$ or model $(I I)$. The superscripts $* * *, * *$, and * denote significance at the $1 \%, 5 \%$, and $10 \%$ level, respectively. 
Table 7: Marginal effects analysis on INC2GDP

\begin{tabular}{|c|c|c|c|c|}
\hline & & (I) & (II) & (III) \\
\hline & $I N C 2 G D P$ & HHLEVERAGE & HOUSECAP & FIXASSETS \\
\hline Description of Marginal Effect & & $\begin{array}{l}\text { Indirect effect of } \\
\text { HHLEVERAGE } \\
\text { on INC2GDP } \\
\text { through } \\
\text { HOUSECAP }\end{array}$ & $\begin{array}{l}\text { Direct Effect of } \\
\text { HOUSECAP on } \\
\text { INC2GDP while } \\
\text { instrumented on } \\
\text { HHELEVERAGE }\end{array}$ & $\begin{array}{l}\text { Direct Effect of } \\
\text { HOUSECAP on } \\
\text { INC2GDP while } \\
\text { instrumented on } \\
\text { HHELEVERAGE }\end{array}$ \\
\hline Regression Coefficient (Table 5) & & -0.095 & -0.338 & 1.177 \\
\hline $\begin{array}{l}\text { Mean of } 5 \text { countries with Lowest } \\
\text { HHLEVERAGE (A) (\%) }\end{array}$ & -0.39 & 2.51 & -0.06 & 0.18 \\
\hline $\begin{array}{l}\text { Mean of } 5 \text { countries with Highest } \\
\text { HHLEVERAGE (B) (\%) }\end{array}$ & -1.20 & 30.24 & 7.00 & -1.16 \\
\hline Low minus High (A-B) (\%) & 0.81 & -27.73 & -7.06 & 1.33 \\
\hline $\begin{array}{l}\text { Incremental Effect on INC2GDP : } \\
\mathrm{C}=(\mathrm{A}-\mathrm{B}) \times \text { Coefficient }\end{array}$ & & 2.63 & 2.39 & 1.57 \\
\hline $\begin{array}{l}\text { Projected INC2GDP of High } \\
\text { HHLEVERAGE countries upon } \\
\text { convergence to Low } \\
\text { HHLEVERAGE levels: C+B (\%) }\end{array}$ & & 1.43 & 1.18 & 0.37 \\
\hline
\end{tabular}

